\title{
Automotive Electrical Learning Module to Improve Students Interest and Learning Achievement of Vocational School
}

\author{
Suyitno $^{1}$, Dwi Jatmoko ${ }^{2}$, Nur Irfan Ardiansyah ${ }^{3}$, Mike Elly Anitasar ${ }^{4}$ \\ \{yitno@umpwr.ac.id ${ }^{1}$,dwijatmoko@umpwr.ac.id ${ }^{2}$, irfan.ardiyan@gmail.com ${ }^{3}$, mike@umpwr.ac.id ${ }^{4}$ \} \\ Universitas Muhammadiyah Purworejo, Indonesia ${ }^{1}$,
}

\begin{abstract}
This research aims to discover the feasibility of the automotive electrical learning module at vocational school and Whether or not there is a lack of interest in learning students with the development of Automotive Electrical learning modules in vocational school. This research uses quasi experimental research. The instruments which used to assessing the feasibility of modules is in the form of questionnaires. While the data analysis used normality, homogenity and students's t-test ( $t$ test). The results of the research analysis showed that product validation by material experts as well as media experts, small group trials and product use trials showed that the material in the form of automotive electrical learning modules was proper to use. Then in the calculation of the one samples test obtained the control mean is 67.50 and the experiment is 81.43 . The results of the difference in the experimental class using the automotive electrical learning module is all of the 14 students succeeded in improving their learning outcomes.
\end{abstract}

Keywords:Module, Interest, Learning Outcomes, Automotive Electrical

\section{Introduction}

Vocational education is an education that specifically learns materials which may be used in workplaces [1]. The word "specific" in this context refers to the vocational education detailed learning of workplace competences. General education is known to learn generally. Yet, vocational education learns materials that are more specific. Stated that vocational education is an overall experience concept for every individual who learns for their success at workplaces [2] [3].

Development comes from the word "develop" and suffix "-ment" which means a process of gradual change towards a higher [4], wider, and deeper level that creates perfection and maturity. Module is a learning material packed in an intact and systematic ways that covers a set of planned and designed learning experience in order to help learners master a specific learning purpose [5] [6]. Learning means a change in behavior and performance with a set of activities such as reading [7] [8], observing, listening, imitating, etc. Learning would become more efficient if done by the learners, instead of only as a verbal compulsion. In addition, Learning Interest refers to learners' high tendency and passion, or a huge desire towards certain matter [9] [7]. Learning results are abilities possess by the learners as a result of their behavior in learning and may be observed through the learners' performance [10] [11].

Automotive electricity is one of the skills that should be owned by every Light Vehicle Engineering graduate [12]. Hence, the learning of automotive electricity system competence 
must be done maximally. Based on the direct observation conducted on December 24, 2017 in vocational school A Yani Gebang Purworejo with students of XI TKR as the subject of research, there are several problems that are found, which includes: (1) The frequently monotonous teaching and learning between teachers and students during the automotive electricity course; (2) The students' lack of attention and interest when the teacher explains about automotive electricity. From the observation, it is found that students prefer to involve in their own activities, such as playing and talking with their fellow students; (3) The data obtained show that the students' score for automotive electricity has not met the minimum completeness criteria, which is 75 . The students have not reached a full understanding of the material due to the lack of learning sources and references used in learning and teaching process of automotive electricity course [13]. Automotive electricity is one of the most important courses for students of Vocational High School in the XI class.

According to the description of observation result, a learning module on Light Vehicle Electrical Maintenance in vocational school A Yani Gebang Purworejo should be arranged. Therefore, that becomes the reason for the researcher to conduct a research entitled "Automotive Electricity Learning Module Development to Increase Interest and Learning Result in vocational school A Yani Gebang Purworejo". The aim of this research is: to find out the Automotive Electricity module development process within a classroom in vocational school A Yani Gebang Purworejo. Also, it is to find out the changes in students' learning interest by using Automotive Electricity learning module development in vocational school A Yani Gebang Purworejo. This research, additionally, aims to find out the changes in students' learning results by using Automotive Electricity learning module development in vocational school A Yani Gebang Purworejo

\section{Method}

This research uses quasi experimental research. The subject is students of XI class by choosing 14 students as the research object and using automotive electricity learning module. The instruments for this research comprise media expert appraisal, material expert appraisal, and students' appraisal instruments. Data collection instrument is done by using questionnaires. In conducting the research, the collected data will be used to solve existing problems in order for the data to be trustworthy and accurate. The data collection in this research is done using questionnaires [1]. Test/questionnaire, is a data collection technique which is done by providing a set of written questions or statements to the respondents to be answered. Then, the data analysis prerequisite test uses normality, homogeneity, and $t$-test tests.

\section{Result and Discussion}

This teaching Media can be applied in the automotive electricity course. Expert appraisal is a technique to validate or assess feasibility of the module design. The module validation is done by 2 material experts and 2 media experts. 
Table 1. Media and material expert validation result

\begin{tabular}{|c|c|c|c|c|c|}
\hline \multirow[t]{2}{*}{ Media/material } & \multicolumn{2}{|c|}{$\sum x_{i}$} & \multicolumn{2}{|r|}{$\sum x_{i}$} & \multirow[t]{2}{*}{ Percentage } \\
\hline & Lecturer & Teacher & Lecturer & Teacher & \\
\hline Material Expert & 68 & 65 & $94 \%$ & $90 \%$ & $92 \%$ \\
\hline Media Expert & 49 & 50 & $88 \%$ & $89 \%$ & $88 \%$ \\
\hline
\end{tabular}

In the table 1, material expert appraisal, it is found that the number of criterion is $92 \%$, while the media expert appraisal found $88 \%$ criterion. This shows that the teaching module is feasible to be used in the classroom.

Table 2. Module test result

\begin{tabular}{lcc}
\hline \multicolumn{1}{c}{ Test questionnaires } & $\sum x_{i}$ & Percentage \\
\hline Small Group Test & 445 & $89 \%$ \\
Big Group Test & 1338 & $92 \%$ \\
\hline
\end{tabular}

The data is tested on big and small groups on the field. The small group test, which consists of 5 people, shows a number of $89 \%$, while the big group test, which consists of 14 people, shows a number of $90 \%$. This points out that the students' learning interest using the automotive electricity teaching module is feasible and ready to be use.

Table 3. Different Learning Interests

\begin{tabular}{lllll}
\hline \multicolumn{1}{c}{ Class } & $\mathrm{N}$ & Mean & Std. Deviation & Std. Error Mean \\
\hline Experiment & 14 & 57.00 & 2.961 & .791 \\
Control & 14 & 44.07 & 3.710 & .992 \\
\hline
\end{tabular}

Based on the SPSS test result by using One sample $t$ test to differentiate one independent variable [14] [15]. This technique is used to find out whether certain scores are significantly different or not with the median of a sample [14]. The output of tone sample test on learning interest shows that the class used as experiment scored a mean of 57.00, which means there is a difference in learning interests by using a better module categorized as Advanced. Meanwhile, the class control is 44.07, which is not good and categorized as low. Therefore, it is safe to say that the use of electricity teaching module affects the students' learning interest result and may increase the learning result. As a result, the learning interest of XI class students in vocational school becomes more effective by using the automotive electricity teaching module.

The test evaluation analysis result of students' learning between control and experimental class in vocational school A Yani Gebang Purworejo may be seen within the following table:

Table 4. The difference of control and experimental class with Minimum Completeness Criteria score

\begin{tabular}{clcc}
\hline Score/Data & Number of & \multicolumn{2}{c}{ Minimum Completeness 75} \\
& students & Finished & Unfinished \\
\hline Control Result & 14 students & 4 students or $29 \%$ & 10 students or $71 \%$ \\
Experimental Result & 14 students & 12 students or $86 \%$ & 2 students or $14 \%$ \\
\hline
\end{tabular}


As seen from the minimum completeness criteria table of score difference, there are 4 students categorized as finished scores $29 \%$ before the treatment, and 12 students categorized as finished scores $86 \%$ after the treatment, which means that learning using the teaching module seen from minimum completeness criteria experiences an increase. The students are also interested in the automotive electricity teaching module; hence they do not experience boredom [16]. This results in fully understanding the material being delivered.

Based on the $t$ test counting result of one sample test SPSS program that aims to differentiate [14], this technique is used to test the output counting of test of normality [10], which shows the significance score result of control class for 0.200 and significance score of experimental class for 0.118 . Therefore, the second result is considered normal. The homogeneity test [17] result data with levene statistic sig $=0.192>0.05$ means that both data category have variant [18]. Then, within the one sample test counting, mean control of 67.50 and experimental of 81.43 are found. The different results of experimental class using automotive electricity teaching module towards 14 students have proven to increase students' learning result.

\section{Conclusion}

From the result of this research and development, it may be concluded that: The Development Steps of automotive electricity teaching module on XI class students of vocational school A Yani Gebang Purworejo includes define, design, develop, and disseminate. Product validation result done by both material and media expert, small group testing, and product application testing show that the material, which is a teaching module product, is feasible to be used. The comparison result proves that the mean of experimental class is 57.00 and the mean of control class is 44.07. Therefore, according to this result, the learning interest of experimental class is higher than control class. The result of media using electricity teaching module plays an important role in forming students' learning interests. The $\mathrm{T}$ test analysis result using SPSS program on the test of normality counting presents control class' significance score result of 0.200 and experimental class' significance score of 0.118 . Hence, the second result is normal. The data from homogeneity test result with levene statistic sig $=0.192>0.05$ means that both data categories have homogeneous variant. Then from the one sample test counting, it is found that the mean of control is 67.50 and experimental is 81.43 . The different result of experimental class using automotive electricity teaching module towards 14 students has successfully increased students' learning result.

\section{References}

[1] T. Kärner and J. Warwas, "Functional relevance of students' prior knowledge and situational uncertainty during verbal interactions in vocational classrooms: Evidence from a mixed-methods study," Empir. Res. Vocat. Educ. Train., vol. 7, no. 1, 2015.

[2] S. Cuendet, J. Dehler-Zufferey, C. Arn, E. Bumbacher, and P. Dillenbourg, "A study of carpenter apprentices' spatial skills,” Empir. Res. Vocat. Educ. Train., vol. 6, no. 1, pp. 1-16, 2014.

[3] S. Hof and M. S. Leiser, "Teaching in vocational education as a second career," Empir. Res. Vocat. Educ. Train., vol. 6, no. 1, pp. 1-13, 2014.

[4] S. Berger, From the Assistant Editor, vol. 10, no. 1. Springer International Publishing, 1987.

[5] K. H. Silber and W. R. Foshay, "Handbook of improving performance in the workplace, instructional design and training delivery," vol. 2009, pp. 709-717, 2009. 
[6] M. Grill, A. Pousette, K. Nielsen, R. Grytnes, and M. Törner, "Supervisors and teachers' influence on expectations on empowering leadership among students in vocational education and training," Empir. Res. Vocat. Educ. Train., vol. 9, no. 1, 2017.

[7] C. Schellenberg, A. Krauss, A. Hättich, and K. Häfeli, "Occupational career patterns over 30 years: Predictors and outcomes," Empir. Res. Vocat. Educ. Train., vol. 8, no. 1, 2016.

[8] M. B. Savin and C. M. Howell, "Foundations Of Problem-Based Learning," 2004.

[9] D. Allan, "Dealing with disaffection: The influence of work-based learning on 14-16-year-old students' attitudes to school," Empir. Res. Vocat. Educ. Train., vol. 6, no. 1, pp. 1-18, 2014.

[10] J. Balatti and S. Black, Constructing Learners as Members of Networks. 2011.

[11] B. Trilling and C. Fadel, "Century Skills," 21St Century Ski., no. Book, 2009.

[12] S. Suyitno, I. Widiyanto, and binti masrul Suryaneta, "DEVELOPMENT OF LEARNING MEDIA FOR THE COURSE OF TWO-STROKE GASOLINE MOTORS TO IMPROVE STUDENTS 'LEARNING OUTCOMES,' J. Pendidik. Teknol. dan Kejuru., vol. 24, no. 1, pp. 83-90, 2018.

[13] S. Suyitno and P. Pardjono, "INTEGRATED WORK-BASED LEARNING ( I-WBL ) MODEL DEVELOPMENT IN LIGHT VEHICLE ENGINEERING COMPETENCY," J. Pendidik. Vokasi, vol. 8, no. 1, pp. 1-11, 2018.

[14] J. Sangmeister, "Commercial competence: Comparing test results of paper-and-pencil versus computer-based assessments," Empir. Res. Vocat. Educ. Train., vol. 9, no. 1, 2017.

[15] J. C. Kaufman, J. A. Plucker, and J. Baer, Essentials of Creativity Assessment. 2008.

[16] M. Fjellström, "Vocational education in practice: A study of work-based learning in a construction programme at a Swedish upper secondary school," Empir. Res. Vocat. Educ. Train., vol. 6, no. 1, pp. 1-20, 2014.

[17] N. Perry and D. Sherlock, QALITY IMPROVEMENT in Adult Vocational Education and Training, Transforming Skills for the Gloabal Economy.

[18] B. M. Minkovich and Y. Y. Makhnenko, Optimal'Noe Vozbuzhdenie Antenn Amplitudnykh Pelengatorov, Rabotayushchikh Po Metodu Sravneniya., vol. 22, no. 3. 1979. 